\title{
Chapter 7 \\ The Impact and Control of Emerging and Re-Emerging Viral Diseases in the Environment: An African Perspective
}

\author{
Juliet Adamma Shenge and Adewale Victor Opayele
}

\subsection{Introduction}

The emergence of new infectious diseases is characterized by a sudden invasion or spread of diseases typically known to be rare or uncommon (Morens et al. 2008). Emerging viruses are newly recognized or newly evolved viruses or those that occurred previously in a population but show increased incidence or expansion into new geographical, host or vector range (WHO 2004). Re-emerging viruses, on the other hand, include those viruses that had previously decreased in incidence but are currently experiencing an upsurge (Morse 1995). These agents present significant challenges to researchers regarding their epidemiology, vaccine design and eradication (Ahmed et al. 2014).

Approximately $80 \%$ of viruses that infect humans are zoonotic (Taylor et al. 2001). Most of these viruses perpetuate naturally in animal reservoirs that include numerous mammalian, avian and invertebrate vectors or intermediate hosts (Woolhouse and Gowtage-Sequeria 2005; Kilpatrick and Randolph 2012). Farm and wild animals are the primary sources of novel zoonotic viruses causing disease in human. This gives rise to about $60 \%$ of known human pathogens and up to $75 \%$ of emerging human infections (Cleaveland et al. 2001). Outbreaks of several viral haemorrhagic diseases have been reported in Africa, majorly caused by viruses in the families Filoviridae, Arenaviridae, Flaviviridae and Bunyaviridae. Animal reservoirs have been involved in the emergence of these viruses in humans. Hence, the transmission of these infectious agents from animals to humans, or vice versa, has resulted in the sustained periodic dissemination in the human population.

\footnotetext{
J. A. Shenge $(\square) \cdot$ A. V. Opayele

Department of Virology, College of Medicine, University of Ibadan, Ibadan, Nigeria
} 


\subsection{Environmental Sources and Patterns of Emergence of New Viral Agents}

The emergence patterns of new viral agents and re-emergence of already known ones have been continuously changing, mostly due to several factors that could be climatic, agricultural, anthropological or a combination of two or more of these factors (Andrew and Gregory 2008). Viruses cannot replicate outside the living host but can survive in the environment for a long period. For instance, enteroviruses are very stable in harsh environments. Several waterborne viruses have been isolated from contaminated sources such as sewage. Such enteric viruses include norovirus, hepatitis $\mathrm{A}$ and $\mathrm{E}$ viruses, human enterovirus A-D, and human adenovirus A-G. These viruses have been implicated in gastrointestinal problems and responsible for infections such as hepatitis, conjunctivitis, poliomyelitis and several others (La Rosa et al. 2012). Other known sources of emerging viral diseases are wild and domestic animals responsible for most zoonotic viral infections (Woolhouse et al. 2005). Again, human involvement in numerous activities to harness natural resources, coupled with other essential factors such as increased residencies, close contacts with animal reservoirs in the wild, poor land use leading to degradation and alteration of natural habitations, have been implicated in the emergence of new infectious diseases. A host of disease-causing microorganisms including viruses in the environment in Africa are not often detected, probably due to inadequate evaluation of the environment. Residential areas sited close to dumpsites and stagnant water sources face hazards of air pollution which poses serious threats to human health. This is commonplace in most urban cities in the continent. Humans interact with such environments through activities such as scavenging at dumpsites, fishing and washing in contaminated water making these sites primary sources of infections, which could subsequently spread through the community (van Doorn 2014). Exchanges through trade, coupled with human and animal travels, have also contributed to the spread of virus-carrying vectors from one region to another (Tatem et al. 2006; Hufnagel et al. 2004). Human-animal-environment connections have resulted in cyclical events that promote infectious disease epidemiology. Zoonotic infectious diseases are most implicated in this pattern, depicted by disease transmission from animals to humans or vice versa and result in disease outbreaks among the human population. It is believed that new viral agents emerge when known viruses from animals switch hosts and become established in humans. This occurrence can lead to severe epidemics when the human-human transmission is achieved, especially with highly pathogenic viruses (Olsen et al. 2006). The viral agents can be airborne and so transmitted through droplets, as in the case of influenza viruses. They can also be transmitted through direct animal bites and scratches such as the rabies virus in dogs and cats; other viral agents such as HIV-1 in primates and SARS-CoV in bats undergo host switching over time to cause epidemics in humans (Parish et al. 2008). Thus, restricted human contact with primates and other virus reservoirs in the wild is notably a significant obstacle to the establishment of viral infections and the occurrence of outbreaks in the human population. 
Infectious disease agents may resurface with fresh features which may include altered or mutated genes resulting in resistance to several antimicrobial agents as in the case of HIV/AIDS, viral hepatitis and influenza. Evolutionary studies have shown that infectious agents that occasionally cause endemics originated and stabilized with time in a given environment (Center for Disease Control and Prevention 2018).

\subsection{Drivers of Emerging Viral Diseases}

Increases in the movement of people, climate change, and viral evolution involving cross-species at the human-animal interface lead to the emergence of new viruses (Parish et al. 2008; Ippolito and Rezza 2017). Environmental factors such as inadequate water supply, sanitation, food and climatic changes, as well as lapses associated with the collection, treatment and disposal of solid waste in developing nations often result to pollution of soil, water and air. This creates breeding sites for biological vectors of viral diseases such as insects and rodents (Obi and Shenge 2018). A likely trend is the dispersal of insect vectors such as Aedes mosquitoes implicated in the spread of many arboviruses which have spread to new locations by adopting new breeding sites in tyres, overcrowded settings and stagnant water pools, mainly because of population growth and expansion. Most are as a result of massive settlements and residential building in unapproved sites such as marshy areas and near dumpsites lacking basic sanitation and proper waste disposal facilities (Marston et al. 2014). In such areas, solid and open waste such as tyres, cans, plastic bottles, and nylon bags that collect water become breeding sites for vectors of viral agents.

Climatic factors like temperature, rainfall and relative humidity influence the incidence, duration and intensity of the emergence of epidemic forms of viral diseases. For example, it has been observed that the incidence of Rift Valley fever in East Africa at a time increased as a result of long periods of heavy rainfall, which created increased breeding sites for the vectors of the disease (Davies et al. 1985). Microbial adaptation in any environment is driven by factors which range from host to agent and ecological influences. Hosts factors include gender, age, and immune status, among others, which may determine the outcome of infection in an exposed host. Additionally, human activities and individual behaviours may influence the transmission of viral diseases. Evolution of viruses resulting in cross-species transmission has also been tagged as a driver of emerging viruses. This is mainly seen among rapidly evolving viruses such as RNA viruses, which are prone to error during replication (Drake and Holland 1999), due to lack of proofreading machinery by the RNA-dependent RNA polymerases (Smith et al. 1997). This results in nucleotide substitutions (mutations) due to rapid replication and synthesis of enormous virus quantity within a short time (Moya et al. 2004). The distribution of viral variants in the human population can be due to epidemics through different means of transmission (Parish et al. 2014). Such diversities have been observed in some RNA 
viruses such as the HIV and hepatitis C virus (Argentini et al. 2009; Shenge et al. 2018).

Another critical driver of the emergence of viral diseases is host switching, where a virus that initially infected an animal host shifts to a new host and subsequently gets established within the human population after it is successfully transmitted (Lindstrom et al. 2004). Host switching enables these viral agents to adapt as a result of recombination and assortment in their genomes, which may lead to the emergence of entirely new strains of the virus or strains with reassorted gene segments. This trend was observed in the 1957 H2N2, and 1968 H3N2 Influenza, human pandemic viruses containing gene segments of haemagglutinin (HA) and polymerase (PB1) obtained from the avian influenza virus (Webby and Webster 2001).

\subsection{Epidemiology, Transmission and Impact of some Emerging Viral Diseases in Africa}

\subsubsection{Rift Valley Fever}

Rift Valley fever (RVF) is a devastating mosquito-borne zoonotic disease that causes illnesses in humans and animals (Hartman 2017). The virus is a Phlebovirus in the family Bunyaviridae. It has a tri-segmented, single-stranded RNA genome in which two segments, L (large) and M (medium), have a negative polarity, while the third, $\mathrm{S}$ (small), is ambisense (Ly and Ikegami 2016). The virus was first isolated from sheep in Kenya in 1931 and has since spread to other countries (Pepin et al. 2010). Large outbreaks of the disease have occurred in many African countries, Madagascar and the Arabian Peninsula, and have usually been indicated by a sweep of abortion in livestock (Mariner 2018). The RVF virus is transmitted through bites of various species of Aedes and Culex mosquitoes which serve as reservoirs and amplifying vectors, respectively. The virus can also be transmitted through contact with infective animal tissues such as blood, aborted foetus and other body fluids (Nyakarahuka et al. 2018). Humans have also been infected through drinking of raw, unpasteurized milk from infected animals (Ng'ang'a et al. 2016).

The RVF virus is maintained during the dry season in desiccation-resistant vertically infected eggs of several Aedes species (Lumley et al. 2017). RVF epizootics and epidemics usually occur during periods of above normal and prolonged rainfall. The rainfall events result in flooding of dambo-type grassland depressions at greater depths and for extended periods compared to interepizootic periods. Consequently, previously dormant infected Aedes eggs are induced to hatch, causing the emergence and survival of at least one large generation of virus-infected Aedes mosquitoes (Williams et al. 2016). These mosquitoes then transmit the virus to ungulate livestock, especially sheep, cattle and goats which serve as amplifying vertebrate hosts that may begin the epizootic cycle. After infection from primary Aedes vectors, livestock species, especially sheep, suffer significant morbidity, mortality and 
up to $100 \%$ abortion. These amplifying vertebrates develop high viraemia, enough to infect secondary mosquito vector species (Lutomiah et al. 2014). Secondary mosquito species including Culex and Mansonia species then serve as the primary horizontal vectors of the RVF virus between viraemic domestic animals and humans. The pace of the epizootic may be further compounded because virus-infected moribund ungulates display little mosquito avoidance behaviour and are preferentially fed upon by secondary vectors (Linthicum et al. 2016).

Notable epidemics of the virus include the 1977 outbreak in Egypt, where about 200,000 human cases and 598 deaths occurred (Meegan et al. 1979). In 2006, an outbreak with over 1000 human cases and 300 deaths occurred in Somalia, Kenya and Tanzania (Dar et al. 2013). Other series of large-scale RVF outbreaks include Sudan (2007), Madagascar (2008), southern Africa (2008-2011), Mauritania (2010, 2012) and Saudi Arabia and Yemen (2000) (Clark et al. 2018). Subclinical circulation of the virus in humans and animals has also been documented in many African countries, including Nigeria (Opayele et al. 2018). This virus severely affects the health and economy of thousands of humans and livestock in the affected countries (Linthicum et al. 2016).

\subsubsection{Yellow Fever}

Yellow fever, caused by the yellow fever virus (YFV), is another mosquito-borne viral haemorrhagic disease with high mortality. It mostly occurs in Africa and South America. Historically, it caused large outbreaks in Europe and North America when it was introduced during the slave trade (Holbrook 2017).

The yellow fever virus possesses a positive-sense, single-stranded RNA genome. It is the prototype of the genus Flavivirus, family Flaviviridae, which comprises approximately 70 viruses, most of which are arthropod borne. Other major human and veterinary pathogens in the genus include dengue, Japanese encephalitis and West Nile viruses (McLinden et al. 2017).

Yellow fever is a zoonotic disease, maintained in nature by non-human primates and diurnally active mosquitoes that breed in tree holes in the forest canopy (Haemagogus spp. in the Americas, and Aedes spp. in Africa). People are exposed to infected mosquitoes when they encroach on this cycle during occupational or recreational activities (Hanley et al. 2013). In the warm, humid savanna regions of Africa, tree-hole-breeding Aedes mosquitoes reach very high densities and are implicated in the endemic and epidemic transmission of viruses from monkeys to humans. Aedes aegypti, a domestic mosquito species that breeds in human-made containers, transmits the yellow fever virus among humans in cities (Possas et al. 2018). The virus is maintained over the dry season by vertical transmission in mosquitoes. Transovarially infected eggs survive in dry tree-holes and hatch infectious mosquitoes when the wet season begins (Monath 2001).

Approximately 200,000 cases of yellow fever occur annually worldwide, $90 \%$ of which occurs in Africa. A striking resurgence of the disease has occurred since the 
1980s in both sub-Saharan Africa and South America (Monath and Vasconcelos 2015). Studies on yellow fever outbreaks across Africa revealed that epidemics of the disease were more frequent and more extensive in west and east African countries than countries in central Africa. This is due to the influence of climate and the environment on both mosquito vectors and the virus (Hamlet et al. 2018). Also, the periodicity of an upsurge in yellow fever activities in west African countries is between 5 and 20 years while much longer intervals of up to 45 years have been observed in parts of east Africa. Some countries have also sustained epidemics across multiple years, for example, in Ghana (1977-1983), Guinea (2000-2005), and Nigeria (1986-1994) (Monath and Vasconcelos 2015). In December 2015, another urban outbreak of yellow fever was declared in Angola and soon after in the Democratic Republic of Congo (DRC). These outbreaks ended in 2017 with 7334 suspected cases and 393 deaths (Kraemer et al. 2017). In 2016, another outbreak occurred in Uganda, and since then, several sporadic yellow fever cases have been reported in Chad, Ghana, the Republic of Congo, Guinea and Nigeria (Domingo et al. 2018).

Mosquito vectors capable of transmitting yellow fever exist in regions where the disease does not presently occur, such as Asia (Barnett 2007). Vector-control strategies that were once successful for the elimination of yellow fever from many affected regions have failed, leading to the re-emergence of the disease. Consequently, the administration of vaccines is still the most effective method of prevention of the disease, coupled with the prevention of mosquito bites. Effective vaccines against yellow fever have been discovered since 1937 (Theiler and Smith 1937) and have been responsible for the significant reduction in occurrences of the disease worldwide (Garske et al. 2014). Till date, the yellow fever 17D vaccine is very effective despite its use for over seven decades probably due to the genetic stability of the yellow fever virus structural proteins which the host immune cells target (Baba and Ikusemoran 2017). However, despite this success, effective administration of the vaccine is still a challenge and has been contributing to the resurgence of the disease in many African countries. There have been occasional issues of supply and demand, as experienced in Angola and Democratic Republic of Congo in 2016 (Barrett 2017). Inadequate vaccine coverage is also a problem in many countries where the disease is endemic (Shearer et al. 2017).

\subsubsection{Lassa Fever}

Lassa fever (LF) is a rodent-borne disease associated with an acute and potentially fatal haemorrhagic illness. It is caused by the Lassa virus (LASV), a member of the family Arenaviridae. The viral genome consists of two single-stranded RNA segments, a small (S) and large (L). Both genomic segments have an ambisense gene organization, encoding two genes in the opposite orientation (Günther and Lenz 2004). The virus was first isolated in 1969 from a nurse who presumably acquired the infection from one of her patients in Lassa town, northeastern Nigeria (Frame 
et al. 1970). The Lassa virus was initially thought to be endemic only in the West African countries of Sierra Leone, Guinea, Liberia and Nigeria (Monath et al. 1974; Lukashevich et al. 1993; Frame et al. 1984; Tomori et al. 1988; O'Hearn et al. 2016). However, its presence has also been reported in other countries including Ivory Coast, Mali, Ghana, Senegal, Burkina Faso, Gambia and the Central African Republic (Frame 1975; Safronetz et al. 2010).

Lassa virus is transmitted through contact with body fluids or excreta, or inhalation of aerosols produced by infected rodents. Hunting and consumption of peridomestic rodents as a source of food have also been reported as another route of virus transmission to humans (Ter Meulen et al. 1996). The infection also spreads between humans through contact with body fluids of infected persons or contaminated medical equipment (Fisher-Hoch et al. 1995). The Lassa virus infects approximately 500,000 people and causes about 5000 deaths worldwide (Mateer et al. 2018). In endemic regions, seropositivity for Lassa virus-specific antibodies could be as high as 55\% in populations residing around forested areas harbouring large populations of reservoir rodents (Lukashevich et al. 1993). Most times, early diagnosis of the infection is missed as most early symptoms are mild and resemble those of other diseases like typhoid fever and malaria in endemic areas (Safronetz et al. 2010).

The multimammate mouse, Mastomys natalensis, is the primary host for the LASV (Lecompte et al. 2006). The virus has little or no adverse effect on its rodent reservoir under natural circumstances (Mariën et al. 2017). Mastomys natalensis is widely distributed throughout West, Central and East Africa (Lopez and Mathers 2006), where they aggregate in houses in large numbers during the dry and harmattan season due to harsh environmental conditions and dispersing into gardens and farmlands when the rains return (Fichet-Calvet et al. 2007). Infected rodents remain carriers of the virus throughout life; the virus is shed in urine, faeces, saliva, respiratory secretion and exposed blood vessels through micro or macro trauma (Keenlyside et al. 1983). In endemic countries, other common rodent species such as Rattus rattus and Mus minutoides have also been implicated in Lassa virus transmission (Wulff et al. 1975).

Lassa fever infects humans of all age groups and sexes. The disease is associated with a broad spectrum of clinical manifestations. The incubation period ranges from 7 to 21 days (McCormick et al. 1987). The clinical presentation is usually mild or asymptomatic in about $80 \%$ of infections (Richmond and Baglole 2003). The onset of the symptomatic disease is usually gradual, starting as a flu-like illness characterized by mild fever, weakness and general malaise. This may be accompanied by a headache, sore throat, muscle pain, chest pain, nausea, vomiting, diarrhoea, cough and abdominal pain (Bausch et al. 2001). In mild cases, the fever subsides, and the patient usually recovers. Other cases progress towards a more severe illness. Symptoms include haemorrhage, respiratory distress, facial oedema and fluid in the pulmonary cavity. Shock, seizures, tremor, disorientation and coma have also been reported during this stage of the disease, indicating a poor prognosis for the disease outcome (Mertens et al. 1973). Approximately 15-20\% of hospitalized Lassa fever patients die from the illness, generally within 2 weeks after the onset of symptoms 
due to multi-organ complication and failure involving the liver, spleen or kidneys. Pregnant women are more likely to have severe illness due to infection with LASV than women who are not pregnant, with maternal case fatality rates as high as $80 \%$ and nearly $100 \%$ mortality in foetuses. Infection in infants can result in "swollen baby syndrome" with oedema, abdominal distension, bleeding and often death (McCormick et al. 1987). Neurological problems, including hearing loss and encephalopathy, have been shown to occur in patients who survive the disease (Mateer et al. 2018).

\subsubsection{Ebola Haemorrhagic Fever (EHF)}

The Ebola virus belongs to the family Filoviridae and the order Mononegavirales. The virus causes haemorrhagic fever, an important emerging viral infection in central Africa. The Ebola virus was first identified in 1976 following two outbreaks of haemorrhagic fever in northern Zaire (the present Democratic Republic of Congo) and southern Sudan. The most highly virulent strain (subtype) is Ebola-Zaire, which has a mortality rate of 88\%. Between 2014 and 2016, several outbreaks of the Ebola virus disease were reported in parts of west Africa, where more than 28,000 cases were confirmed with over 11,000 deaths in Liberia, Guinea, Sierra Leone, Democratic Republic of Congo (DRC) and Nigeria (Baize et al. 2014). As of August 31, 2018, about 120 cases and 78 deaths had been confirmed from DRC alone (WHO 2018).

Contact with infected live animals such as bats, their excretions or carcass of infected animals causes primary infection, which subsequently results in sustained person-to-person transmission as have been observed in Ebola and Marburg viruses over the years (Groseth et al. 2007).

\subsubsection{Other Emerging Viral Diseases}

Viral disease outbreaks occur periodically with the potential to increase in incidence. Their unique nature allows the viruses to change their form and evade the hosts' immune defence to produce persistent or latent infections, or worse still, an outbreak in any population. This attribute has enabled the emergence of novel or pandemic variants among several viral agents, including influenza virus (Meseko et al. 2013, 2014). Typically, new infections emerge as a result of changes in existing strains that can lead to resistance or due to some environmental factors that support the growth of emerging infectious agents, in a particular geographical zone. A typical example is the emergence of several subtypes of the influenza virus over time, as a result of re-assortment and mutation in animal reservoirs, especially birds and swine, with major variants such as $\mathrm{H} 1 \mathrm{~N} 1, \mathrm{H} 1 \mathrm{~N} 2$ and $\mathrm{H} 3 \mathrm{~N} 2$, now being detected at the human-animal interface (Alexander and Brown 2000; Yu et al. 2009). Other 
newly identified viral agents include severe acute respiratory syndrome (SARS) virus and species or strains that have a significant burden on public health and global economies.

\subsection{Methods of Detection and Identification of Emerging Viruses}

The early detection of emerging viral agents is vital in the management and control of diseases. Several measures that facilitate clinical and epidemiological investigation of emerging viral diseases in any environment have been identified (Chan et al. 2017). Such measures involve rapid detection of viral agents using the most sensitive and specific laboratory assays, including viral antigen and antibody testing, isolation of viral agents using cell and tissue culture techniques, molecular characterization, including nucleic acid synthesis and amplification with polymerase chain reaction (PCR), genotyping and genomic sequencing. The use of quantitative molecular tools such as real-time reverse transcription PCR for enumerating RNA viruses, especially during outbreaks, has helped in the identification of new viral agents (Marston et al. 2014). These advanced techniques enable rapid diagnosis and identification of cases and contacts within a short period.

The successful detection of an emerging virus may depend on the type of procedure used, and this, in turn, can be determined by economic, human resources and laboratory robustness at the time. Serological techniques, including antigen and antibody testing, involve the use of labelled enzymes and their substrates as indicators in enzyme-linked immunosorbent assays (ELISA) (Whitehouse 2004). These methods are inexpensive and used mostly in clinical settings in Africa to detect viruses using serum or plasma obtained from blood. However, because the methods are time-consuming and not sensitive enough to detect occult and early infections, rapid detection of a viral agent may be eluded when using such methods, especially among individuals with nonspecific symptoms of the disease (Whitehouse 2004).

Molecular tools such as PCR and genome sequencing remain the gold standard for identifying emerging and re-emerging viruses (Rosenstierne et al. 2014). PCR is a very sensitive technique, which involves the amplification of the viral genetic material (DNA or RNA), even at very low concentrations, in the specimen for easy identification, regardless of the stage of infection. Methods such as real-time PCR complement the techniques involving antigen and antibody testing (Wang et al. 2011). It is best suited for early diagnosis in clinical samples and during viral diseases outbreaks such as Marburg or Ebola (Weidmann et al. 2007). Molecular techniques are, however, costly, requiring substantial funding to acquire equipment and reagents. Another limitation is the need for trained laboratory personnel. These limitations hinder the use of molecular techniques for the diagnosis of viral infections, including emerging and re-emerging ones, in most African countries given that the methods cannot be used for routine clinical diagnosis. 
The detection of emerging viruses may also be achieved through the screening of vertebrate or arthropod hosts of tropical viral diseases. Samples from these animals (bats, rodents, ticks, non-human primates, birds and vectors such as mosquitoes and fleas) can be routinely screened for an array of viral agents using PCR and microarray analysis (Rosenstierne et al. 2014).

\subsection{Prevention, Control and Management}

Novel epidemics and increased incidence of emergent and re-emergent diseases highlight the need for the development of effective control strategies. A major challenge in controlling these diseases results from the fact that their transmission intensity is driven primarily by wildlife reservoirs. Therefore, one-sided disease prevention enacted either by the human or animal health sector is often inefficient (Lembo 2012). The following approaches have been recognized as suitable and effective in the control of zoonotic viral diseases.

\subsubsection{Surveillance}

There is a need for constant surveillance of emerging viral diseases in all countries around the world. Constant surveillance is needed to monitor trends in epidemiological patterns of disease occurrence. To achieve this, humans and animals need to be tested regularly to detect the presence of disease agents before the occurrence of epidemics. Considering the current ease of transportation especially through the air, it is possible for commercial aircraft to transport infected humans and vectors from one part of the world to another. For example, the Rift Valley fever introductions into Egypt in 1977 and the Arabian Peninsula in 2000 followed epizootics in Sudan in 1976 and the Horn of Africa in 1998, respectively. Also, the potential for such globalization of other arboviruses has been demonstrated in the case of West Nile and Chikungunya viruses over the past 15 years (Nash et al. 2001; Cassadou et al. 2014).

Effective surveillance in Africa is, however, a challenge due to the remoteness of some communities, especially in rural settings without access to good road infrastructure. For example, a study conducted in Zambia revealed that the lack of transportation facilities was among the leading contributing factors challenging the implementation of an integrated disease surveillance and response strategy in the country (Mandyata et al. 2017). Similarly, a review of the challenges faced by 18 African countries in implementing adequate surveillance schemes identified the lack of transportation as a significant compounding factor (Phalkey et al. 2013). This challenge has further been demonstrated by a recent study that reported that 
improved transportation networks led to improved case reporting, hence, disease surveillance in Uganda in 2016 (Nakiire et al. 2019).

\subsubsection{Control in Animals}

In order to prevent the transmission of viral agents to new locations through the movement of animals, quarantine is strongly advocated for some infectious diseases, especially when animals are moved over long distances, as with livestock import-export, pet trade and tourism. This has been the case with the prevention of spread of the Ebola virus (Gumusova et al. 2015). Immunization of exposed animals is also essential in the control of vaccine-preventable animal diseases. Vaccination campaigns have been shown to greatly assist in the control of numerous different zoonotic diseases such as rabies and the Rift Valley fever. However, vaccination can only be done for owned animals. With a high number of stray animals, like dogs, in Africa, both approaches (quarantining and immunization) may not prove effective for control of infections like rabies, for example (Leung and Davis 2017; Salomão et al. 2017).

\subsubsection{Control of Vectors and Reservoirs}

The control of vectors and reservoirs includes measures to prevent zoonotic pathogens from being transmitted to non-infected animals, humans and disease-free areas, through arthropod vectors, contaminated fomite and animal reservoirs. This may involve improving hygiene and control of the environment. For instance, the control of yellow fever during the construction of the Panama Canal in the early twentieth century is linked to the destruction of Aedes breeding sites which included draining of pools of standing water and grass cutting (Center for Disease Control and Prevention 2015). Arthropod vector control is another effective strategy in reducing sources of infection, as in the case of Rift Valley fever, yellow fever and other mosquito-borne zoonoses. Rodent control and avoidance of bush burning, setting traps in and around homes to reduce rat population and avoiding contact with rats are other effective methods of reducing contact with animal reservoirs of dangerous pathogens like Lassa fever virus. To achieve such effective control, adequate sanitation would be an absolute necessity. However, most African countries are far from achieving the set global sanitation goals of 2030 as detailed in the Sustainable Development Goals (Nhamo et al. 2019). Thus, without adequate sanitation, the control of vectors within African countries would be challenged, hence the control of emerging and re-emerging viral pathogens. 


\subsubsection{Prevention in Man}

Humans are important in the control of zoonosis. Much of the success of disease control plans depends on health education. Public awareness of health risks connected with certain infections can greatly assist in reducing the spread of such diseases (Hasanov et al. 2018). Occupational health education should be explicitly directed at categories of workers that are exposed to certain diseases in the course of their duties. These include farmers, veterinarians, personnel in slaughterhouses and biological laboratories (Cripps 2000). Vaccination is also very useful in protecting at-risk individuals against diseases for which vaccines have been developed.

Proper food hygiene, including safe dietary habits, is of value in dealing with some diseases like Rift valley fever, which can be transmitted by the consumption of unpasteurized milk and dairy products (Ng'ang'a et al. 2016). The cooking of meat and meat products before consumption and high standards of hygiene in kitchens and catering facilities are also needed in the control of emerging diseases like Lassa fever. Improved sanitation from better sewage and drinking water treatment will also help in control and prevention strategies (Mara et al. 2010).

Often, emerging infectious diseases have the potential to spread rapidly in hospital settings. It is, therefore, important for healthcare workers to adhere strictly to infection control measures. Isolation of infected patients, barrier nursing of infected patients and the use of personal protective equipment (PPE) when caring for patients have been shown to reduce nosocomial outbreaks of Lassa fever and other haemorrhagic diseases (Helmick et al. 1986).

\subsection{Conclusion}

Africa is among the hot zones for zoonotic and emerging viral diseases, which may continue to result in the emergence of new viruses. Constant evaluation of water, soil, air and other sources for viral pollution, as well as proper disposal and treatment of wastewater, is suggested as a way forward to tackling the emergence of viral infections in Africa's environment.

Human activities, including agriculture and exploitation of forest resources, will continue to bring humans closer to sylvatic cycles of zoonotic viruses. These activities could also alter the natural population and geographic distributions of insect and animal, which serves as vectors or reservoirs for these viruses, thereby leading to the emergence of new viruses and re-emergence of known ones. Rapid globalization also increases the risk that infections that emerge in one part of the world can spread internationally in human and animal populations. Currently, vaccines for the prevention of many of these viruses are unavailable, and the public health delivery system is weak in many African countries where most of the emerging and remerging viruses are known to occur. There is, therefore, the need for consistent surveillance and monitoring of these diseases of epidemic and pandemic potential. 
Surveillance and monitoring information will allow for timely alerts and effective response activities that will prevent major outbreaks in Africa and beyond. There is also the need to invest more resources in the development of vaccines for more of these emerging viruses. Increased investment in public health infrastructures, transportation and sanitation facilities are also required in the control of these viruses.

\section{References}

Ahmed SM, Hall AJ, Robinson AE, Verhoef L, Premkumar P, Parashar UD, Koopmans M, Lopman BA (2014) Global prevalence of norovirus in cases of gastroenteritis: a systematic review and meta-analysis. Lancet Infect Dis 14:725-730

Alexander D, Brown IH (2000) Recent Zoonoses caused by influenza a viruses. OIE Sci Tech Rev 19:197-225

Andrew P, Gregory EG (2008) Emerging viral diseases. Md Med 9(1):11-16

Argentini C, Genovese D, Dettori S, Rapicetta M (2009) HCV genetic variability: from quasispecies evolution to genotype classification. Future Microbiol 4:359-373

Baba MM, Ikusemoran M (2017) Is the absence or intermittent YF vaccination the major contributor to its persistent outbreaks in eastern Africa? Biochem Biophys Res Commun 492:548-557. https://doi.org/10.1016/j.bbrc.2017.01.079

Baize S, Pannetier D, Oestereich L, Reiger T, Koivogui L, Magassouba N, Soropogui B, Sow MS, Keita S, De Clerck H, Tiffany A, Dominguez G et al. (2014) Emergence of Zaire Ebola Virus Disease in Guinea. N Engl J Med 371:1418-1425

Barnett ED (2007) Yellow fever: epidemiology and prevention. Clin Infect Dis 44:850-856. https:// doi.org/10.1086/511869

Barrett ADT (2017) Yellow fever live attenuated vaccine: a very successful live attenuated vaccine but still we have problems controlling the disease. Vaccine 35:5951-5955. https://doi. org/10.1016/j.vaccine.2017.03.032

Bausch DG, Demby AH, Coulibaly M et al (2001) Lassa fever in Guinea: I. epidemiology of human disease and clinical observations. Vector Borne Zoonotic Dis 1:269-281. https://doi. org/10.1089/15303660160025903

Cassadou S, Boucau S, Petit-Sinturel M et al (2014) Emergence of chikungunya fever on the French side of Saint Martin island, October to December 2013. Euro Surveill 19. https://doi. org/10.2807/1560-7917.ES2014.19.13.20752

Center for Disease Control and Prevention (2015) CDC - Malaria - About Malaria - History The Panama Canal. https://www.cdc.gov/malaria/about/history/panama_canal.html. Accessed 9 Oct 2018

Center for Disease Control and Prevention (2018) Emerging Infectious Diseases. Emerging Infectious Disease (EID) Journal ISSN: 1080-6059.

Chan JF, Sridhar S, Yip CC, Lau SK, Woo PC (2017) The role of laboratory diagnostics in emerging viral infections: the example of the Middle East respiratory syndrome epidemic. J Microbiol 55(3):172-182

Clark MHA, Warimwe GM, Di Nardo A et al (2018) Systematic literature review of Rift Valley fever virus seroprevalence in livestock, wildlife and humans in Africa from 1968 to 2016. PLoS Negl Trop Dis 12:e0006627. https://doi.org/10.1371/journal.pntd.0006627

Cleaveland S, Laurenson MK, Taylor LH (2001) Diseases of humans and their domestic mammals: pathogen characteristics, host range and the risk of emergence. Philos Trans R Soc B Biol Sci 356(1411):991-999

Cripps PJ (2000) Veterinary education, zoonoses and public health: a personal perspective. Acta Trop 76:77-80. https://doi.org/10.1016/S0001-706X(00)00094-2 
Dar O, McIntyre S, Hogarth S, Heymann D (2013) Rift Valley fever and a new paradigm of research and development for zoonotic disease control. Emerg Infect Dis 19. https://doi.org/10.3201/ eid1902.120941

Davies FG, Linthicum KJ, James AD (1985) Rainfall and epizootic Rift Valley fever. Bull World Health Organ 63(5):941-943

Domingo C, Charrel RN, Schmidt-Chanasit J et al (2018) Yellow fever in the diagnostics laboratory review-article. Emerg Microbes Infect 7:129

Drake JW, Holland JJ (1999) Mutation rates among RNA viruses. PNAS 96(24):13910-13913

Fichet-Calvet E, Lecompte E, Koivogui L et al (2007) Fluctuation of abundance and Lassa virus prevalence in Mastomys natalensis in Guinea, West Africa. Vector Borne Zoonotic Dis 7:119128. https://doi.org/10.1089/vbz.2006.052

Fisher-Hoch SP, Tomori O, Nasidi A et al (1995) Review of cases of nosocomial Lassa fever in Nigeria: the high price of poor medical practice. BMJ 311:857-859. https://doi.org/10.1136/ bmj.311.7009.857

Frame JD (1975) Surveillance of Lassa fever in missionaries stationed in West Africa. Bull World Health Organ 52:593-598

Frame JD, Baldwin JM, Gocke DJ, Troup JM (1970) Lassa fever, a new virus disease of man from West Africa. I. Clinical description and pathological findings. Am J Trop Med Hyg 19:670 676. https://doi.org/10.1371/journal.pntd.0000548

Frame JD, Yalley-Ogunro JE, Hanson AP (1984) Endemic Lassa fever in Liberia. V. Distribution of Lassa virus activity in Liberia: hospital staff surveys. Trans R Soc Trop Med Hyg 78:761-763. https://doi.org/10.1016/0035-9203(84)90012-9

Garske T, Van Kerkhove MD, Yactayo S et al (2014) Yellow fever in Africa: estimating the burden of disease and impact of mass vaccination from outbreak and serological data. PLoS Med. https://doi.org/10.1371/journal.pmed.1001638

Groseth A, Feldmann H, Strong JE (2007) The ecology of Ebola virus. Trends Microbiol 15(9):408-416

Gumusova S, Sunbul M, Leblebicioglu H (2015) Ebola virus disease and the veterinary perspective. Ann Clin Microbiol Antimicrob 14(30). https://doi.org/10.1186/s12941-015-0089-x

Günther S, Lenz O (2004) Lassa virus. Crit Rev Clin Lab Sci 41:339-390. https://doi. org/10.1080/10408360490497456

Hamlet A, Jean K, Perea W et al (2018) The seasonal influence of climate and environment on yellow fever transmission across Africa. PLoS Negl Trop Dis 12:e0006284. https://doi. org/10.1371/journal.pntd.0006284

Hanley KA, Monath TP, Weaver SC et al (2013) Fever versus fever: the role of host and vector susceptibility and interspecific competition in shaping the current and future distributions of the sylvatic cycles of dengue virus and yellow fever virus. Infect Genet Evol 19:292-311. https:// doi.org/10.1016/j.meegid.2013.03.008

Hartman A (2017) Rift Valley fever. Clin Lab Med 37:285-301. https://doi.org/10.1016/j. cll.2017.01.004

Hasanov E, Zeynalova S, Geleishvili M et al (2018) Assessing the impact of public education on a preventable zoonotic disease: rabies. Epidemiol Infect 146:227-235. https://doi.org/10.1017/ S0950268817002850

Helmick CG, Webb PA, Scribner CL et al (1986) No evidence for increased risk of Lassa fever infection in hospital staff. Lancet 2:1202-1205

Holbrook MR (2017) Historical perspectives on Flavivirus research. Viruses 9(5):E97. https://doi. org/10.3390/v9050097

Hufnagel L, Brockmann D, Geisel T (2004) Forecast and control of epidemics in a globalized world. Proc Natl Acad Sci U S A 101:15124-15129

Ippolito G, Rezza G (2017) Preface - emerging viruses: from early detection to intervention. Adv Exp Med Biol 972:1-5 
Keenlyside RA, McCormick JB, Webb PA et al (1983) Case-control study of Mastomys natalensis and humans in Lassa virus-infected households in Sierra Leone. Am J Trop Med Hyg 32:829837. https://doi.org/10.4269/ajtmh.1983.32.829

Kilpatrick AM, Randolph SE (2012) Drivers, dynamics, and control of emerging vector-borne zoonotic diseases. Lancet 380(9857):1946-1955

Kraemer MUG, Faria NR, Reiner RC et al (2017) Spread of yellow fever virus outbreak in Angola and the Democratic Republic of the Congo 2015-16: a modelling study. Lancet Infect Dis 17:330-338. https://doi.org/10.1016/S1473-3099(16)30513-8

La Rosa G, Fratini M, della Libera S, Iaconelli M, Muscillo M (2012) Emerging and potentially emerging viruses in water environments. Ann Ist Super Sanita 48(4):397-406

Lecompte E, Fichet-Calvet E, Daffis S et al (2006) Mastomys natalensis and Lassa fever, West Africa. Emerg Infect Dis 12:1971-1974. https://doi.org/10.3201/eid1212.060812

Lembo T (2012) The blueprint for rabies prevention and control: a novel operational toolkit for rabies elimination. PLoS Negl Trop Dis. https://doi.org/10.1371/journal.pntd.0001388

Leung T, Davis SA (2017) Rabies vaccination targets for stray dog populations. Front Vet Sci 4:52. https://doi.org/10.3389/fvets.2017.00052

Lindstrom SE, Cox NJ, Klimov A (2004) Genetic analysis of human H2N2 and early H3N2 influenza viruses, 1957-1972: evidence for genetic divergence and multiple reassortment events. Virology 328:101-119

Linthicum KJ, Britch SC, Anyamba A (2016) Rift Valley fever: an emerging mosquito-borne disease. Annu Rev Entomol 61:395-415. https://doi.org/10.1146/annurev-ento-010715-023819

Lopez AD, Mathers CD (2006) Measuring the global burden of disease and epidemiological transitions: 2002-2030. Ann Trop Med Parasitol 100:481-499. https://doi.org/10.1179/1364859 $06 \times 97417$

Lukashevich IS, Clegg JC, Sidibe K (1993) Lassa virus activity in Guinea: distribution of human antiviral antibody defined using enzyme-linked immunosorbent assay with recombinant antigen. J Med Virol 40:210-217. https://doi.org/10.1002/jmv.1890400308

Lumley S, Horton DL, Hernandez-Triana LLM et al (2017) Rift valley fever virus: strategies for maintenance, survival and vertical transmission in mosquitoes. J Gen Virol 98:875-888

Lutomiah J, Omondi D, Masiga D et al (2014) Blood meal analysis and virus detection in bloodfed mosquitoes collected during the 2006-2007 Rift Valley fever outbreak in Kenya. Vector Borne Zoonotic Dis 14:656-664. https://doi.org/10.1089/vbz.2013.1564

Ly HJ, Ikegami T (2016) Rift Valley fever virus NSs protein functions and the similarity to other bunyavirus NSs proteins. Virol J 13:118. https://doi.org/10.1186/s12985-016-0573-8.

Mandyata CB, Olowski LK, Mutale W (2017) Challenges of implementing the integrated disease surveillance and response strategy in Zambia: a health worker perspective. BMC Public Health 17(1):746. https://doi.org/10.1186/s12889-017-4791-9.

Mara D, Lane J, Scott B, Trouba D (2010) Sanitation and health. PLoS Med 7:e1000363. https:// doi.org/10.1371/journal.pmed.1000363

Mariën J, Borremans B, Gryseels S et al (2017) No measurable adverse effects of Lassa, Morogoro and Gairo arenaviruses on their rodent reservoir host in natural conditions. Parasit Vectors. https://doi.org/10.1186/s13071-017-2146-0

Mariner J (2018) Rift Valley fever surveillance. FAO Animal Production and Health Manual No. 21. Food and Agriculture Organization of the United Nations (FAO), Rome

Marston HD, Folkers GK, Morens DM, Fauci AS (2014) Emerging Viral Diseases: Confronting Threats with New Technologies. Sci Transl Med 6(253):253ps10-253ps10

Mateer EJ, Huang C, Shehu NY, Paessler S (2018) Lassa fever-induced sensorineural hearing loss: a neglected public health and social burden. PLoS Negl Trop Dis 12:e006187. https://doi. org/10.1371/journal.pntd.0006187

McCormick JB, King IJ, Webb PA et al (1987) A case-control study of the clinical diagnosis and course of Lassa fever. J Infect Dis. https://doi.org/10.1093/INFDIS/155.3.445 
McLinden JH, Bhattarai N, Stapleton JT et al (2017) Yellow fever virus, but not Zika virus or dengue virus, inhibits T-cell receptor-mediated T-cell function by an RNA-based mechanism. J Infect Dis 216:1164-1175. https://doi.org/10.1093/infdis/jix462

Meegan JM, Hoogstraal H, Moussa MI (1979) An epizootic of Rift Valley fever in Egypt in 1977. Vet Rec 105:124-125. https://doi.org/10.1136/vr.105.6.124

Mertens PE, Patton R, Baum JJ, Monath TP (1973) Clinical presentation of Lassa fever cases during the hospital epidemic at Zorzor, Liberia, march-April 1972. Am J Trop Med Hyg 22:780-784

Meseko CA, Odaibo GN, Olaleye DO (2014) Detection and isolation of 2009 pandemic influenza a/H1N1 virus in commercial piggery, Lagos Nigeria. Vet Microbiol 168(1):197-201. https:// doi.org/10.1016/j.vetmic.2013.11.003

Meseko CA, Olaleye DO, Capua I, Cattoli G (2013) Swine influenza in sub-Saharan Africa- current knowledge and emerging insights. Zoonoses Public Health:2013. https://doi.org/10.1111/ zph. 12068

Monath TP (2001) Yellow fever: an update. Lancet Infect Dis 1:11-20

Monath TP, Newhouse VF, Kemp GE et al (1974) Lassa virus isolation from Mastomys natalensis rodents during an epidemic in Sierra Leone. Science 185:263-265. https://doi.org/10.1126/ science.185.4147.263

Monath TP, Vasconcelos PFC (2015) Yellow fever. J Clin Virol 64:160-173

Morens DM, Folkers GK, Fauci AS (2008) Emerging infections: a perpetual challenge. Lancet Infect Dis 8:710-719

Morse SS (1995) Factors in the emergence of infectious diseases. Emerg Infect Dis 1(1):7-15

Moya A, Holmes EC, Gonzalez-Candelas F (2004) The population genetics and evolutionary epidemiology of RNA viruses. Nat Rev 2:279-288

Nakiire L, Masiira B, Kihembo C, Katushabe E, Natseri N, Nabukenya I, Komakech I, Makumbi I, Charles O, Adatu F, Nanyunja M, Nsubuga P, Woldetsadik SF, Tusiime P, Yahaya AA, Fall IS, Wondimagegnehu A (2019) Healthcare workers' experiences regarding scaling up of training on integrated disease surveillance and response (IDSR) in Uganda, 2016: cross sectional qualitative study. BMC Health Serv Res 19(1):117. https://doi.org/10.1186/s12913-019-3923-6

Nash D, Mostashari F, Fine A et al (2001) The outbreak of West Nile virus infection in the new York City area in 1999. N Engl J Med 344:1807-1814. https://doi.org/10.1056/ NEJM200106143442401

Ng'ang'a CM, Bukachi SA, Bett BK (2016) Lay perceptions of risk factors for Rift Valley fever in a pastoral community in northeastern Kenya. BMC Public Health 16:32. https://doi.org/10.1186/ s12889-016-2707-8

Nhamo G, Nhemachena C, Nhamo S (2019) Is 2030 too soon for Africa to achieve the water and sanitation sustainable development goal? Sci Total Environ 669:129-139

Nyakarahuka L, de St. Maurice A, Purpura L et al (2018) Prevalence and risk factors of Rift Valley fever in humans and animals from Kabale district in Southwestern Uganda, 2016. PLoS Negl Trop Dis 12:e0006412. https://doi.org/10.1371/journal.pntd.0006412

O'Hearn AE, Voorhees MA, Fetterer DP et al (2016) Serosurveillance of viral pathogens circulating in West Africa. Virol J 13:163. https://doi.org/10.1186/s12985-016-0621-4

Obi RK, Shenge JA (2018) The environment and transmission of viral diseases. In: Okoye CU, Abah D (eds) Dynamics of natural resource and environment in Nigeria; theory, practice, bureaucracy, advocacy. DEBEES Printing and Publishing Company, Enugu, Nigeria. pp 66-78

Olsen B, Munster VJ, Wallensten A, Waldenstrom J, Osterhaus AD, Fouchier RA (2006) Global patterns of influenza a virus in wild birds. Science 312:384-388

Opayele AV, Odaibo GN, Olaleye OD (2018) Rift valley fever virus infection among livestock handlers in Ibadan, Nigeria. J Immunoass Immunochem 39:609-621. https://doi.org/10.1080/ 15321819.2018.1525739

Parish F, Sirin A, Charman D, Joosten H, Minayeva T, Silvus M, Stringer L (2008) Assessment on Peatlands, Biodiversity and Climate Change: Main Report; Global Environment Centre, Kuala Lumpur and Wetland International; Wageningen 
Parish CR, Holmes EC, Morens DM, Park EC, Burke DS, Calisher CH, Laughlin CA, Saif LJ, Daszak P (2008) Cross-species virus transmission and the emergence of new epidemic diseases. Microbiol Mol Biol Rev 72:457-470

Parish IA, Marshall HD, Staron HD, Lang PA, Brüstle A, Chen JH, Cui W, Tsui YC, Perry C, Laidlaw BJ, Ohashi P, Weaver CT, Kaech SM (2014) Chronic viral infection promotes sustained Th1-derived immunoregulatory IL-10 via BLIMP-1. Journal of Clinical Investigation 124(8):3455-3468

Pepin M, Bouloy M, Bird BH et al (2010) Rift Valley fever virus (Bunyaviridae: Phlebovirus): an update on pathogenesis, molecular epidemiology, vectors, diagnostics and prevention. Vet Res 41(61). https://doi.org/10.1051/vetres/2010033

Phalkey RK, Yamamoto S, Awate P, Marx M (2013) Challenges with the implementation of an integrated disease surveillance and response (IDSR) system: systematic review of the lessons learned. Health Policy Plan 30(1):131-143

Possas C, Lourenço-de-Oliveira R, Tauil PL et al (2018) Yellow fever outbreak in Brazil: the puzzle of rapid viral spread and challenges for immunisation. Mem Inst Oswaldo Cruz 113:e180278. https://doi.org/10.1590/0074-02760180278

Richmond JK, Baglole DJ (2003) Lassa fever: epidemiology, clinical features, and social consequences. BMJ 327:1271-1275. https://doi.org/10.1136/bmj.327.7426.1271

Rosenstierne MW, McLoughlin KS, Olesen ML, Papa A, Gardner SN, Engler O, Plumet S, Mirazimi A, Weidmann M, Neidrig M, Fomsgaard A, Erlandsson L (2014) The microbial detection Array for detection of emerging viruses in clinical samples- a useful Panmicrobial diagnostic tool. PLoS One 9(6):e100813. https://doi.org/10.1371/journal.pone.0100813

Safronetz D, Lopez JE, Sogoba N et al (2010) Detection of Lassa virus, Mali. Emerg Infect Dis 16:1123-1126. https://doi.org/10.3201/eid1607.100146

Salomão C, Nacima A, Cuamba L, Gujral L, Amiel O, Baltazar C, Cliff J, Gudo ES (2017) Epidemiology, clinical features and risk factors for human rabies and animal bites during an outbreak of rabies in Maputo and Matola cities, Mozambique, 2014: implications for public health interventions for rabies control. PLoS Negl Trop Dis 11(7):e0005787. https://doi. org/10.1371/journal.pntd.0005787

Shearer FM, Moyes CL, Pigott DM et al (2017) Global yellow fever vaccination coverage from 1970 to 2016: an adjusted retrospective analysis. Lancet Infect Dis. https://doi.org/10.1016/ S1473-3099(17)30419-X

Shenge JA, Odaibo GN, Olaleye DO (2018) Genetic diversity of hepatitis C virus among blood donors and patients with clinical hepatitis in Ibadan Nigeria. Arch Basic Appl Med 6(1):79-85

Smith DS, Pathirana S, Davidson F, Lawlor E, Power J, Yap PL, Simmonds P (1997) The origin of hepatitis C virus genotypes. J Gen Virol 78:321-328

Tatem AJ, Hay SI, Rogers DJ (2006) Global traffic and disease vector dispersal. Proc Natl Acad Sci U S A 103:6242-6247

Taylor LH, Latham SM, Woolhouse MEJ (2001) Risk factors for human disease emergence. Philos Trans R Soc B Biol Sci 356(1411):983-989

Ter Meulen J, Lukashevich I, Sidibe K et al (1996) Hunting of peridomestic rodents and consumption of their meat as possible risk factors for rodent-to-human transmission of Lassa virus in the Republic of Guinea. Am J Trop Med Hyg 55:661-666. https://doi.org/10.4269/ ajtmh.1996.55.661

Theiler M, Smith DS (1937) The Use of Yellow Fever Virus Modified by in Vitro Cultivation for Human Immunization. J Exp Med 65(6):787-800

Tomori O, Fabiyi A, Sorungbe A et al (1988) Viral hemorrhagic fever antibodies in Nigerian populations. Am J Trop Med Hyg 38:407-410. https://doi.org/10.4269/ajtmh.1988.38.407

van Doorn RH (2014) Emerging infectious diseases. Medicine (Abingdon) 42(1):60-63

Wang Y, Zhang X, Wei H (2011) Laboratory detection and diagnosis of filoviruses. Virol Sin 26:73-80

Webby RJ, Webster RG (2001) Emergence of influenza a viruses. Philos Trans R Soc Lond B 356:1817-1828 
Weidmann M, Hufert FT, Sall AA (2007) Viral load among patients infected with Maburgvirus in Angola. J Clin Virol 39:65-66

Whitehouse CA (2004) Crimean-Congo hemorrhagic fever. Antivir Res 64:145-160

WHO (2004) Report of the WHO/FAO/OIE joint consultation on emerging zoonotic diseases/in collaboration with the health Council of the Netherlands. World Health Organization, Geneva. http://www.who.int/iris/handle/10665/68899

WHO (2018) Update on Ebola Outbreak and Emergency Preparedness and Response in DRC. Accessed September 3, 2018.

Williams R, Malherbe J, Weepener H et al (2016) Anomalous high rainfall and soil saturation as combined risk indicator of rift valley fever outbreaks, South Africa, 2008-2011. Emerg Infect Dis 22:2054-2062. https://doi.org/10.3201/eid2212.151352

Woolhouse ME, Haydon DT, Antia R (2005) Emerging pathogens: the epidemiology and evolution of species jumps. Trends Ecol Evol 20:238-244

Woolhouse MEJ, Gowtage-Sequeria S (2005) Host range and emerging and Reemerging pathogens. Emerg Infect Dis 11(12):1842-1847

Wulff H, Fabiyi A, Monath TP (1975) Recent isolations of Lassa virus from Nigerian rodents. Bull World Health Organ 52:609-613

Yu H, Zhou YJ, Li GX et al (2009) Further evidence for infection of pigs with human-like H1N1 influenza viruses in China. Virus Res 140:85-90 